
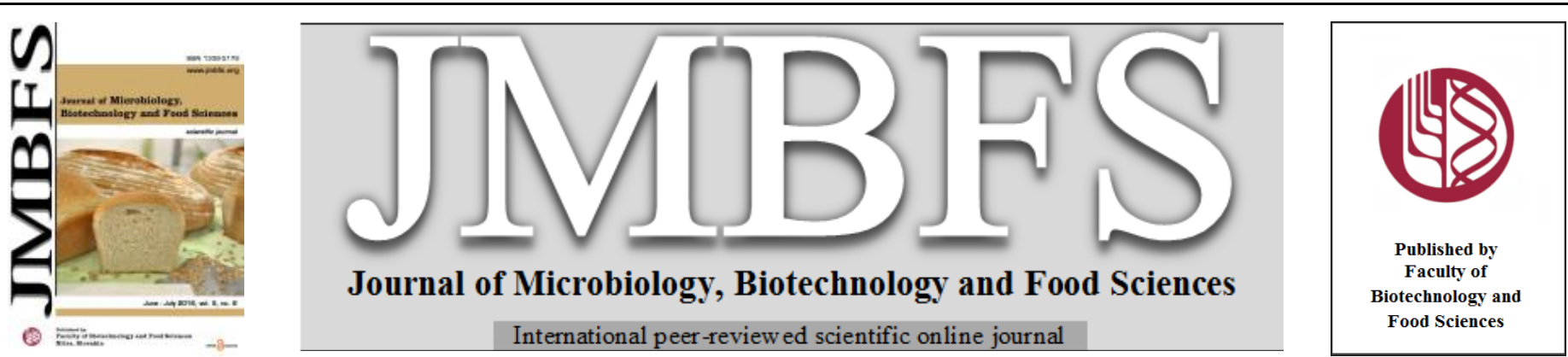

\title{
PRESERVING THE QUALITY AND PROLONGATION THE SHELF-LIFE OF BEEF PACKED UNDER VACUUM OR MODIFIED ATMOSPHERE USING TERNARY ANTIOXIDANT BLEND
}

\author{
Alexander Stoyanov Staykov ${ }^{1}$, Stefan Georgiev Dragoev ${ }^{2}$, Dessislav Kostadinov Balev ${ }^{2}$, Dessislava Borislavova Vlahova- \\ Vangelova ${ }^{2}$, Miglena Rumenova Pavlova ${ }^{2}$
}

Address(es):

${ }^{1}$ Regional Directorate of Food Safety, Bulgarian Agency of Food Safety, 4 N. Canov str., 4400 Pazardjik, Bulgaria.

${ }^{2}$ Department of Meat and Fish Technology, Technological Faculty, University of Food Technologies, 26 Maritz blvd., 4002 Plovdiv, Bulgaria.

*Corresponding author: logos20001t@gmail.com

doi: 10.15414/jmbfs.2016.5.6.617-622

ARTICLE INFO

Received 5. 10. 2014

Revised 28. 2. 2016

Accepted 1.3.2016

Published 1. 6. 2016

Regular article

open $\mathcal{O}$ access

\begin{abstract}
Keeping the quality and prolongation the shelf-life of stored at $0 \pm 0.5^{\circ} \mathrm{C}$ packed under vacuum or modified $\left(80 \% \mathrm{O}_{2} / 20 \% \mathrm{CO}_{2}\right)$ atmosphere beef $m$. semimembranosus sprayed with $0.02 \%$ solution, containing 10 g. $1^{-1}$ dihydroquercetin from Siberian larch (Larix sibirica Ledeb), $5 \mathrm{~g} .1^{-1}$ rosemary (Rosmarinus officinalis) extract and $1 \mathrm{~g} . \mathrm{l}^{-1} \mathrm{~L}$-ascorbic acid was studied. The experiments were carried out with five samples: control - air packaged; vacuum packaged; vacuum packaged and treated with $0.02 \%$ ternary antioxidant blend; packaged under modified atmosphere $\left(80 \% \mathrm{O}_{2} / 20 \% \mathrm{CO}_{2}\right)$; and packaged under rich in oxygen modified atmosphere, after spaying with $0.02 \%$ ternary antioxidant blend. Samples were stored 28 days (to $32 \mathrm{~d}$ post mortem) at $0 \pm 0.5^{\circ} \mathrm{C}$. The pre-treatment of beef with ternary antioxidant blend preserve the sensory scores and colour properties of beef, and inhibited total microbial growth, and development of Brochothrix termosphacta and pathogens to the end of storage $\left(28 \mathrm{~d}\right.$ at $\left.0 \pm 0.5^{\circ} \mathrm{C}\right)$, was found. The pre-treatment of beef with ternary antioxidant blend was not main factors which can affect the $\mathrm{pH}$ and free amino nitrogen changes in fresh beef. The pre-treatment of beef with $0.02 \%$ ternary antioxidant blend may be successfully used for preserving the quality and prolonging the shelf-life of beef $m$. semimembranosus packed under modified $\left(80 \% \mathrm{O}_{2} / 20 \% \mathrm{CO}_{2}\right)$ atmosphere. The shelf-life can extend with $75 \%$ compared to air packed meat, and with 7 days against only vacuum- or modified atmosphere packed beef.
\end{abstract}

Keywords: Natural antioxidants, vacuum, modified atmosphere packaging, meat, sensory properties, colour, microbiological status

\section{INTRODUCTION}

The main criterions in purchasing fresh beef on the market are its colour, flavour, odour and microbiological status (Ercolini et al., 2006). The sensory properties are the most important factor determining the meat quality. That is way, the extension of the quality and shelf-life of packed chilled beef was one of necessity to meet the demands of consumers (Lagerstedt et al., 2011). In this respect, increasing attention was put on the packaging conditions. Vacuum packed meat changes its colour from bright-red to purple-brown during refrigeration (Blix and Borch, 2002). The reason is conversion of muscle oxymyoglobin in metmyoglobin (Mancini and Hunt, 2005). By controlling the levels of residual oxygen in the package, prevention of this negative phenomenon is achieved. The rich in oxygen modified atmosphere packaging (MAP) preserves muscle oxymyoglobin two times longer, compared to air-packed meat (Lagerstedt et al., 2011). Unfortunately, the high-oxygen MAP system induces lipid and myoglobin oxidation and protein polymerization (Kim et al., 2010). Better oxidative, microbial and colour stability can be achieve when combined the effect of antioxidants and MAP (Lund et al., 2007; Rojas and Brewer, 2007).

For extending the shelf-life of the MAP $\left(70 \% \mathrm{O}_{2} / 20 \% \mathrm{CO}_{2} / 10 \% \mathrm{~N}_{2}\right)$ beef was used rosemary or vitamin $C$ solutions (Djenane et al., 2003). Lund et al. (2007) offered the protein and lipid oxidation in MAP $\left(100 \% \mathrm{~N}_{2}\right.$, or $\left.80 \% \mathrm{O}_{2} / 20 \% \mathrm{~N}_{2}\right)$ minced beef patties stored for 6 days in the dark at $4{ }^{\circ} \mathrm{C}$, to be inhibit by addition of rosemary extract or ascorbate/citrate (1:1) mixture. Natural antioxidants such as rosemary extracts (Rohlik et al., 2010, 2012) and dihydroquercetin (Semenova et al., 2008; Bakalivanova and Kaloyanov, 2012) have been proposed for prolongation of the shelf-life of meat products and especially the MAP beef (Fernández-López et al., 2005; Balev et al., 2010).

Rosemary extracts (RE) were able to scavenge the free hydroxyl radicals converting them into stable products (Djenane et al., 2003; Brewer, 2011). The aqueous extract of rosemary (Rosmarinus officinalis Linn.) contains phenolic diterpenes (carnosic, carnosol, rosmanol, rosmadial, 12-methoxycarnosic acid, epi-, and iso-rosmanol) and phenolic acids (rosmarinic and caffeic) (Brewer, 2011). While carnosic acid also has a single aromatic ring, it has two - $\mathrm{OH}$ groups that can serve as $\mathrm{H}$ donors. The vicinal $-\mathrm{OH}$ groups can chelate pro-oxidative metals thereby preventing oxidation. The polyphenols, rosmarinic acid has two aromatic rings, each with two ${ }^{-} \mathrm{OH}$ groups that are capable of donating $\mathrm{H}^{+}$and chelating metals. In lipid-based systems, carnosic acid and carnosol effectively chelate iron and scavenge peroxyl radical (Djenane et al., 2003; Lund et al., 2007).

The dihydroquercetin (DHQ) is a dihydroflavonol. It is having properties of a powerful free radical-chain terminator (Bakalivanova and Kaloyanov, 2012). The common characteristic of the flavonoids is the basic 15-carbon flavan structure $\left(\mathrm{C}_{6} \mathrm{C}_{3} \mathrm{C}_{6}\right)$. These carbon atoms are arranged in three rings $(\mathrm{A}, \mathrm{B}$, and $\mathrm{C})$ (Brewer, 2011). The free radical-scavenging potential of the dihydroquercetin includes: (1) Phenolic hydroxyls in flavonoids were the main active groups capable of scavenging ${ }^{\bullet} \mathrm{OH},(2)$ Hydroxyl groups in ring B and A were important ${ }^{\circ} \mathrm{OH}$-scavenging active groups, (3) The ortho-dihydroxyl groups in ring A and/or $\mathrm{B}$ could greatly enhance the ${ }^{\circ} \mathrm{OH}$-scavenging activity of the rings, (4) The hydroxyl groups on $3^{\prime}, 4^{\prime}$ position of ring B possessed the highest ${ }^{\bullet} \mathrm{OH}$-scavenging activity compared with hydroxyl groups in ring B, and was higher than that of hydroxyl groups in ring A (Vladimirov et al., 2009). The synergism and antagonism between quercetin and other chain-breaking antioxidants is possible, too (Becker et al., 2007).

$\mathrm{L}$-ascorbic acid (AA) is a source of four -OH groups. AA can donate hydrogen to an oxidizing system, to chelate metal ions (i.e. $\mathrm{Fe}^{2+}$ ), to scavenge free radicals, to quencher the $\mathrm{O}_{2}{ }^{-\bullet}$ radicals, and to acts as a reducing agent (Brewer, 2011). At high levels $\left(>1000 \mathrm{mg} \cdot \mathrm{kg}^{-1}\right)$ AA shifts the balance between ferrous $\left(\mathrm{Fe}^{2+}\right)$ and ferric $\left(\mathrm{Fe}^{3+}\right)$ iron, and acts as an oxygen scavenger. However, at low levels $(<100$ mg. $\mathrm{kg}^{-1}$ ) it can catalyse oxidation in muscle tissue (Yetella and Min, 2008). Lascorbic acid can exert a synergistic effect when added along with polyphenolic antioxidants as play role of metals chelators (Brewer, 2011).

The stored meat loses potential to oxygenate deoxymyoglobin. When beef is packaged under vacuum the oxygen content must be less than $0.05 \%$. Addition of reducing agents is recommended to improve oxygen absorption (Motoyama $\boldsymbol{e t}$ al., 2010). The inhibition of oxidative processes in beef using combination of 
rosemary extracts, as free radical scavengers, which improves and enhances antioxidant effect of dihydroquercetin (Silva et al., 2002) was still not discussed. All the above-mentioned combinations of the treatment of MAP or VP meat with separate antioxidants have not shown a satisfactory effect when it comes to a more prolonged of 21 days storage at $0-4^{\circ} \mathrm{C}$ (Fernández-López et al., 2005; Kim et al., 2010). In the available literature, we did not encounter information on the use of a combination of natural antioxidants and vitamin $\mathrm{C}$, which exhibit a synergistic effect.

That is why, the objective of this study was to determine the effect of surface pre-treatment with of ternary antioxidant blend (TAB) containing dihydroquercetin extracted from Siberian larch (Larix sibirica Ledeb), extract from rosemary (Rosmarinus officinalis Linn.), and L-ascorbic acid on the quality and shelf-life of $\left(80 \% \mathrm{O}_{2} / 20 \% \mathrm{CO}_{2}\right)$ modified atmosphere packed (MAP) or vacuum packed (VP) beef

\section{MATERIALS AND METHODS}

The beef was supplied by the company "Unitemp" Ltd (Voyvodinovo village district Plovdiv, Bulgaria). The carcass quarters were imported from slaughterhouse SC Nicbac ProdSRL (Loc. Nicolae Balcescu village, district Bacau, Romania). The carcasses were deboned, and the m. semimembranosus were packaged on the $4^{\text {th }}$ day post mortem. The $\mathrm{pH}$ of meat was 5.36 , and the temperature at the moment of packaging was around $1^{\circ} \mathrm{C}$.

Three-component antioxidants blend solution was prepared as ten g DHQ and one g AA were dissolved in $25 \mathrm{ml} \mathrm{96 \%} \mathrm{ethanol.} \mathrm{Five} \mathrm{g} \mathrm{RE} \mathrm{were} \mathrm{emulsified} \mathrm{in} 20$ $\mathrm{cm}^{3} 96 \%$ ethanol. Two liquids were mixed. The mixture was filled up to $1 \mathrm{dm}^{3}$ with $950 \mathrm{~cm}^{3}$ bidistilled water.

The powdered dihydroquercetin extract (DHQ) from Siberian larch (Larix sibirica Ledeb) was purchased by Flavit Ltd. (Pushtino, Russia). It contains: $96 \%$ dihydroquercetin, 3\% dihydrokempferol and 1\% naringenin. The powdered rosemary extract (RE) was supplied by Aromena Ltd. (Sofia, Bulgaria). The content of flavonoids was approx. $42 \mathrm{~g} . \mathrm{kg}^{-1}$, and peroxide value $(\mathrm{POV})=0.658 \pm$ 0.018 meqv $\mathrm{O}_{2} \cdot \mathrm{kg}^{-1}$ lipids. The L-ascorbic acid (AA) was purchased from Sigma Chemical Group Pty Ltd. (Balcatta, Perth WA, USA). All rest chemicals and reagents were purchased from E. Merck KGaA (Darmstadt, Germany).

The surfaces of the $50 \mathrm{~kg}$ beef $m$. semimembranosus, with temperature $6.3^{\circ} \mathrm{C}$, were sprayed with $1 \mathrm{dm}^{3} 0.02 \%$ TAB. Samples were strained off for $60 \mathrm{~min}$ at $1.2^{\circ} \mathrm{C}$, and were packaged in transparent polymer bags. The packaged samples were put into plastic boxes, labelled and stored at $0 \pm 0.5^{\circ} \mathrm{C}$ before analysis. One part of examined samples was MAP $\left(80 \% \mathrm{O}_{2} / 20 \% \mathrm{CO}_{2}\right)$. The other part of experimental samples was VP. A packaging machine Yang SR1, model Polaris VAC, Ductto (Como via al Bassone, Italy) was used

The experiments were carried out with 5 groups: control samples C - ai packaged only, samples VP - vacuum packaged only, samples AVP - vacuum packaged and treated with $0.02 \%$ TAB, samples MAP - packaged under modified atmosphere $\left(80 \% \mathrm{O}_{2} / 20 \% \mathrm{CO}_{2}\right)$ only, and samples AMAP - packaged under rich in oxygen $\left(80 \% \mathrm{O}_{2} / 20 \% \mathrm{CO}_{2}\right)$ modified atmosphere, after spaying with $0.02 \% \mathrm{TAB}$ Samples were stored 28 days. The analyses were carried out on: 4 day post mortem (1 day of experiment), 11 day post mortem (7 day of storage), 18 day post mortem (14 day of storage), 25 day post mortem (21 day of storage), and 32 day post mortem (28 day of storage). The samples were obtained according ISO 3100-1:1991. Before analysis samples were stored at $0 \pm 0.5^{\circ} \mathrm{C}$ no more than 6

The panellists making sensory analysis participated in six training sessions and underwent performance testing as specified in guidelines developed by Meilgaard et al. (2006). The panellists were passed the triangular test for differentiation of fresh and rancid meat taste, odor and colour. The beef roast were evaluated by the panellists for aromatics (cooked beef/broth, cooked beef fat, chemical taste, serum/bloody and plum/prune), feeling factors (astringent, metallic and chemical burn) and basic tastes (salt, sour, bitter and sweet). The roast beef samples were also scored using 1-5 scale (Larick and Turner, 1990) Examinations of beef samples were done after the packs opening. The chilled to $0^{\circ} \mathrm{C}$ samples were put in aluminium foil packs and grilled for $20 \mathrm{~min}$ at 200 $250^{\circ} \mathrm{C}$.

The colour measurement was made by colorimeter Konica Minolta model CR 410 (Konica Minolta Holding, Inc., Ewing, New Jersey, USA), purchased by Sending Inc. (Tokyo, Japan). By it was evaluated the brightness of the colour $\left(\mathrm{L}^{*}\right)$, red $(\mathrm{a} *)$ and yellow $(\mathrm{b} *)$ color component (Hunt et al., 2012).

The modified titration method of Sørensen (Lorenzo et al., 2008) was used for free amino nitrogen determination in beef samples.

$\mathrm{pH}$ value of the beef was determined using pH-meter MS 2004 (Microsyst Ltd. Plovdiv, Bulgaria), equipped by combined $\mathrm{pH}$ electrode Sensorex Combination Recorder S 450 CD (Sensorex pH Electrode Station, Garden Grove, CA, USA (Young et al., 2004).

The total aerobic plate count was determined by EN ISO/DIS 4833-2003 (Cohen et al., 2007). The Escherichia coli were estimated according ISO 16649-1:2001 (Nastasijevic et al., 2009). The Salmonella bacteria determinations were carried out following ISO 6579-2002 (Piknová et al., 2002), and the Listeria monocytogenes - using ISO 11290-2002 (Scotter et al., 2004). The Brochothrix termosphacta was determined by BSS ISO 13722:2002 (Russo et al., 2004), and of Enterobacteriaceae spp. - using BSS ISO 21528-1:2011 (Ercolini et al., 2006).

The data were analysed using factorial analysis of variance procedure (mixed procedure) of SAS Version 8.2 software package (SAS Institute Inc., 2002). The model included the main effects and interactions of nine treatments and four storage times. Multiple tests were used to separate means at $95 \%$ significance level for each test.

\section{RESULTS}

\section{Sensory evaluated properties}

At four (C, VP, AVP, and MAP) from five examined samples steadily decreasing average scores for sensory evaluated beef $m$. semimembranosus surface colour during storage at $0 \pm 0.5^{\circ} \mathrm{C}$ were assessed. The only exception were samples AMAP, (Fig 1).

The colour of the samples VP was unacceptable after 28 days of refrigeration storage at $0 \pm 0.5^{\circ} \mathrm{C}(32 \mathrm{~d}$ post mortem $)$. At the end of the experiment $(28 \mathrm{~d})$, the colour of the samples AVP and MAP remains acceptable and their marks undergoes reduction by $27 \%$ and $36 \%$ respectively. The reduction in samples VP was $57 \%$

During the storage period $\left(28 \mathrm{~d}\right.$ at $\left.0 \pm 0.5^{\circ} \mathrm{C}\right)$ the odour's scores of samples $\mathrm{C}$, VP, AVP and MAP decreases significantly $(\mathrm{P}<0.05)$. The only exception was samples AMAP, where the odour scores were very high throughout the studied period and the average values was not significantly $(\mathrm{P}>0.05)$ different to the end of the experiment (Fig 1). Reduction of the smell average scores in samples MAP was $28.0 \%$, while the established decrease in samples AVP was $16.3 \%$

Similarly to the results obtained for smell, in four (C, VP, AVP and MAP) from the five examined samples the scores for taste decreases during the storage period $\left(28 \mathrm{~d}\right.$ at $\left.0 \pm 0.5^{\circ} \mathrm{C}\right)$. The only exception were the samples AMAP. In these samples (AMAP) the taste scores were found very high throughout the studied period and the average values did not significantly $(\mathrm{P}>0.05)$ different by the end of the experiment (Figure 1). After 28 days of refrigeration storage at $0 \pm 0.5^{\circ} \mathrm{C}$ (32 $\mathrm{d}$ post mortem), the flavour of samples VP was completely unacceptable and unpleasant as scores were decreased by $57.1 \%$. The flavour of samples AVP and MAP retained acceptable to the end of the experiment $\left(28 \mathrm{~d}\right.$ at $\left.0 \pm 0.5^{\circ} \mathrm{C}\right)$. The reduction of the flavour scores in samples MAP was 32.0\%, and in samples AVP - $18.4 \%$. Only the combination of the surface treatment of beef $\mathrm{m}$. semimembranosus with $0.02 \% \mathrm{TAB}$, and MAP $\left(80 \% \mathrm{O}_{2} / 20 \% \mathrm{CO}_{2}\right)$, was able to preserve the good sensory properties and to extend the shelf-life of meat to 28 day (or up to 32 day post mortem). The MAP samples demonstrated good sensory properties up to $21^{\text {st }}$ day after packaging (up to 25 day post mortem). During the storage period $\left(28 \mathrm{~d}\right.$ at $\left.0 \pm 0.5^{\circ} \mathrm{C}\right)$ the highest decrease in sensory evaluated colour was established in vacuum packaged beef (Fig 1)

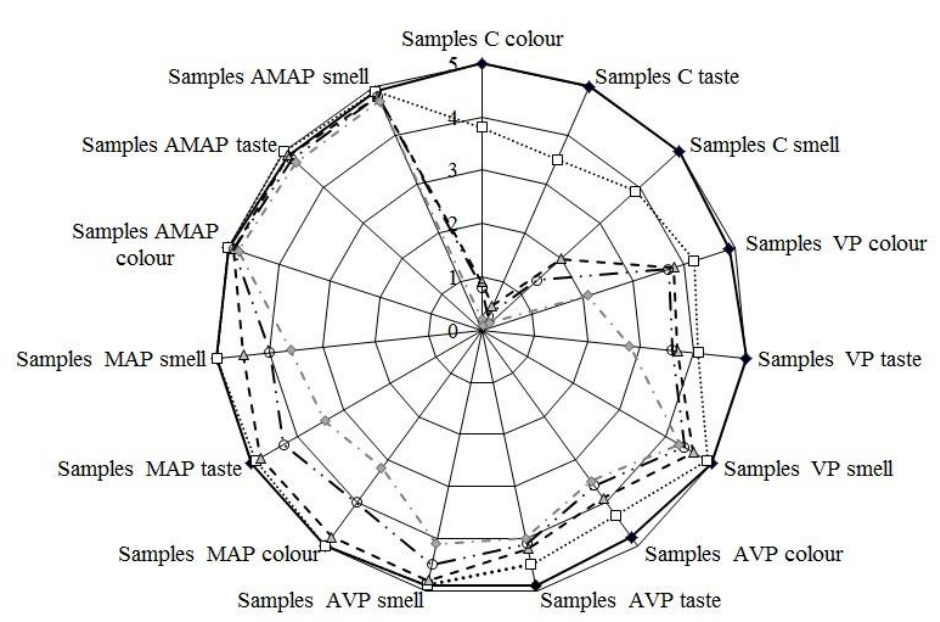
$\rightarrow-1 \mathrm{~d}$ of storage $/ 4 \mathrm{~d}$ post mortem
$-\Delta-14 \mathrm{~d}$ of storage $/ 18 \mathrm{~d}$ post mortem
$-\diamond-28$ of storage $/ 32 \mathrm{~d}$ post mortem.

……7d of storage $/ 11 \mathrm{~d}$ post mortem.

$\rightarrow \cdot 21 \mathrm{~d}$ of storage $/ 25 \mathrm{~d}$ post mortem

Figure 1 Effect of the ternary antioxidant blend superficial treatment on the sensory characteristics of beef $\mathrm{m}$. semimembranosus packaged under vacuum and rich of oxygen modified atmosphere during storage at $0 \pm 0.5^{\circ} \mathrm{C}$.

Legend: samples C - controls only air packaged; samples VP - vacuum packaged only; samples AVP - vacuum packaged and treated superficially with $0.02 \%$ tertiary antioxidant blend; samples MAP - packaged under modified atmosphere 
$\left(80 \% \mathrm{O}_{2} / 20 \% \mathrm{CO}_{2}\right)$ only, samples AMAP - packaged under rich in oxygen $\left(80 \% \mathrm{O}_{2} / 20 \% \mathrm{CO}_{2}\right)$ modified atmosphere, after superficial spaying $0.02 \%$ tertiary antioxidant blend

\section{Instrumentally measured colour characteristics}

The results obtained for instrumentally measured colour characteristics (Table 1) of beef m.-semimembranosus during storage at $0 \pm 0.5^{\circ} \mathrm{C}$ correspond with the data from sensory analysis (Fig 1). During the refrigeration storage ( $28 \mathrm{~d}$ at $0 \pm$ $\left.0.5^{\circ} \mathrm{C}\right)$ the colour lightness $\left(\mathrm{L}^{*}\right)$ of control samples $\mathrm{C}$ significantly $(\mathrm{P} \leq 0.05)$ decrease with $7.33 \%$ comparing with initial values.

Table 1 Effect of the three-component antioxidant blend superficial treatment on the colour characteristics of the external surface of beef $m$. semimembranosus packaged under vacuum and rich of oxygen modified atmosphere during storage at $0 \pm 0.5^{\circ} \mathrm{C}$

\begin{tabular}{|c|c|c|c|c|}
\hline Samples & $\begin{array}{l}\text { Storage time, } \\
\text { days }\end{array}$ & $\begin{array}{l}\text { The colour lightness, } \\
\left(\mathbf{L}^{*}\right)\end{array}$ & $\begin{array}{l}\text { Redness } \\
\left(\mathbf{a}^{*}\right)\end{array}$ & $\begin{array}{l}\text { Yellowness } \\
\left(\text { b }^{*}\right)\end{array}$ \\
\hline \multirow{5}{*}{ Control samples C } & 1d & $38.36^{\mathrm{a}} \pm 0.47$ & $23.55^{\mathrm{a}} \pm 0.49$ & $9.65^{\mathrm{a}} \pm 0.33$ \\
\hline & $7 d$ & $38.37^{\mathrm{a}} \pm 0.46$ & $23.28^{\mathrm{a}} \pm 0.52$ & $9.50^{\mathrm{a}} \pm 0.34$ \\
\hline & 14d & $37.02^{b} \pm 0.39$ & $14.37^{b} \pm 0.48$ & $10.44^{b} \pm 0.46$ \\
\hline & 21d & $36.40^{\mathrm{b}} \pm 0.38$ & $12.83^{c} \pm 0.47$ & $11.83^{c} \pm 0.37$ \\
\hline & 28d & $35.55^{c} \pm 0.43$ & $11.36^{\mathrm{d}} \pm 0.39$ & $12.67^{\mathrm{d}} \pm 0.36$ \\
\hline \multirow{5}{*}{ Samples VP } & 1d & $38.36^{\mathrm{a}} \pm 0.47$ & $23.55^{\mathrm{a}} \pm 0.66$ & $9.65^{\mathrm{a}} \pm 0.33$ \\
\hline & $7 d$ & $38.14^{\mathrm{a}} \pm 0.42$ & $23.26^{\mathrm{a}} \pm 0.50$ & $9.63^{\mathrm{a}} \pm 0.59$ \\
\hline & 14d & $37.27^{b} \pm 0.38$ & $20.40^{b} \pm 0.63$ & $6.77^{b} \pm 0.49$ \\
\hline & 21d & $37.09^{b} \pm 0.34$ & $20.19^{b} \pm 0.53$ & $6.65^{b} \pm 0.37$ \\
\hline & 28d & $36.36^{c} \pm 0.33$ & $19.14^{\mathrm{c}} \pm 0.45$ & $5.90^{\mathrm{c}} \pm 0.35$ \\
\hline \multirow{5}{*}{ Samples AVP } & 1d & $38.36^{\mathrm{a}} \pm 0.47$ & $23.55^{\mathrm{a}} \pm 0.49$ & $9.65^{\mathrm{a}} \pm 0.33$ \\
\hline & $7 d$ & $38.47^{\mathrm{a}} \pm 0.44$ & $23.63^{\mathrm{a}} \pm 0.51$ & $10.58^{b} \pm 0.50$ \\
\hline & $14 d$ & $38.36^{\mathrm{a}} \pm 0.51$ & $22.40^{b} \pm 0.50$ & $10.51^{\mathrm{b}} \pm 0.44$ \\
\hline & 21d & $37.86^{b} \pm 0.45$ & $21.30^{c} \pm 0.43$ & $9.39^{c} \pm 0.39$ \\
\hline & $28 d$ & $36.89^{c} \pm 0.42$ & $20.85^{\mathrm{d}} \pm 0.48$ & $8.67^{d} \pm 0.32$ \\
\hline \multirow{5}{*}{ Samples MAP } & 1d & $38.36^{\mathrm{a}} \pm 0.47$ & $23.55^{\mathrm{a}} \pm 0.39$ & $9.65^{\mathrm{a}} \pm 0.33$ \\
\hline & $7 d$ & $39.96^{\mathrm{b}} \pm 0.46$ & $24.09^{b} \pm 0.36$ & $10.26^{b} \pm 0.56$ \\
\hline & $14 d$ & $39.33^{b} \pm 0.42$ & $23.86^{b} \pm 0.45$ & $11.49^{b} \pm 0.58$ \\
\hline & 21d & $38.42^{\mathrm{c}} \pm 0.32$ & $21.01^{\mathrm{c}} \pm 0.46$ & $12.64^{\mathrm{c}} \pm 0.47$ \\
\hline & $28 d$ & $34.77^{\mathrm{d}} \pm 0.39$ & $16.78^{d} \pm 0.48$ & $14.53^{d} \pm 0.68$ \\
\hline \multirow{5}{*}{ Samples AMAP } & 1d & $38.36^{\mathrm{a}} \pm 0.47$ & $23.55^{\mathrm{a}} \pm 0.39$ & $9.65^{a} \pm 0.33$ \\
\hline & $7 d$ & $38.87^{\mathrm{a}} \pm 0.49$ & $23.56^{\mathrm{a}} \pm 0.36$ & $10.21^{\mathrm{a}, \mathrm{b}} \pm 0.38$ \\
\hline & 14d & $38.49^{\mathrm{a}} \pm 0.47$ & $23.51^{\mathrm{a}} \pm 0.41$ & $10.77^{\mathrm{b}} \pm 0.47$ \\
\hline & 21d & $38.26^{\mathrm{a}} \pm 0.43$ & $23.42^{\mathrm{a}} \pm 0.39$ & $11.01^{\mathrm{b}} \pm 0.43$ \\
\hline & 28d & $37.98^{\mathrm{a}} \pm 0.42$ & $23.18^{\mathrm{a}} \pm 0.33$ & $11.34^{\mathrm{b}} \pm 0.39$ \\
\hline
\end{tabular}

Means \pm standard divinations

$\mathrm{a}, \mathrm{b}, \mathrm{c}, \mathrm{d}$ - indexes show data with statistical different value in columns $(\mathrm{p}<0.05)$

Similarly to the control samples $\mathrm{C}$, the colour lightness $\left(\mathrm{L}^{*}\right)$ in samples VP decreases with $5.21 \%$. However, on $28^{\text {th }}$ day of storage the colour lightness ( $\left.\mathrm{L}^{*}\right)$ of samples MAP was reduced with $9.36 \%(\mathrm{P} \leq 0.05)$. A decrease by $3.83 \%$ in the $\mathrm{L}^{*}$ value of samples AVP was estimated. Only the lightness ( $\left.\mathrm{L}^{*}\right)$ of the samples AMAP does not change significantly $(\mathrm{P}>0.05)$ throughout the 28 day period of the refrigeration storage at $0 \pm 0.5^{\circ} \mathrm{C}$. Our results was similar to the data obtained by Ahn et al. (2002) which determined beef patties containing antioxidants had higher $\mathrm{L}^{*}$ values after $9^{\text {th }}$ day of storage.

The colour redness $\left(\mathrm{a}^{*}\right)$ in four of examined samples (C, VP, AVP, and MAP), decreases significantly $(\mathrm{P} \leq 0.05)$ during 28 days of storage at $0 \pm 0.5^{\circ} \mathrm{C}$. The established decreases were with $51.76 \%, 18.73 \%, 11.46 \%$, and $28.75 \%$ respectively, compared with initial values. For the studied period ( 28 days at $0 \pm$ $\left.0.5^{\circ} \mathrm{C}\right)$ only the $\mathrm{a}^{*}$-values was of samples AMAP was unchanged $(\mathrm{P}>0.05)$.

The results obtained for colour yellowness $\left(\mathrm{b}^{*}\right)$ indicate different trends between beef samples during 28 days storage at $0 \pm 0.5^{\circ} \mathrm{C}$ (Table 1$)$. The $\mathrm{b}^{*}$ values of control samples $\mathrm{C}$ and samples MAP increased significantly $(\mathrm{P} \leq 0.05)$ with $31.3 \%$, and with $50.6 \%$. Superficial pre-treatment of beef with $0.02 \%$ natura antioxidant mixture increases the $b^{*}$ values of rich in oxygen modified packaged samples AMAP only to $17.5 \%$. Contrary, a decreasing of the $b^{*}$ values was observed in VP samples, and was less pronounced in samples AVP (Table 1). After $28^{\text {th }}$ day of storage at $0 \pm 0.5^{\circ} \mathrm{C}$ the colour yellowness $\left(b^{*}\right)$ in samples VP decrease with $38.9 \%$, and in samples AVP - with $10.2 \%$ (Table 1).

\section{pH value}

The $\mathrm{pH}$ of experimental samples VP, AVP, MAP and AMAP increases very slightly, but significantly $(\mathrm{P} \leq 0.05)$ during 28 days of storage at $0 \pm 0.5^{\circ} \mathrm{C}$ (to $32^{\text {nd }}$ day post mortem) (Table 2). The only exception were control samples C, with $18.21 \%$ increase of $\mathrm{pH}$. At the end of the experiment $\left(28 \mathrm{~d}\right.$ at $\left.0 \pm 0.5^{\circ} \mathrm{C}\right)$ maximal increase of the $\mathrm{pH}$ was established in samples MAP and AMAP $(\mathrm{P}>$ $0.05)$. For the studied period $\left(28 \mathrm{~d}\right.$ at $\left.0 \pm 0.5^{\circ} \mathrm{C}\right)$ the $\mathrm{pH}$ of samples VP and AVP increase with $6.38 \%$ and $6.92 \%$ respectively.

\section{Free amino nitrogen}

A significant $(\mathrm{P} \leq 0.05)$ increasing of FAN was determined in all samples (Table 2). After 28 days of storage ( $32 \mathrm{~d}$ post mortem) FAN content in control samples $\mathrm{C}$ raised 27.8 times. The increase in experimental samples was from 15.2 (samples VP) to 15.8 times (sample AVP). During 28 days of refrigeration storage $\left(0 \pm 0.5^{\circ} \mathrm{C}\right)$ the FAN content in test samples does not exceed $10 \mathrm{mg} .100 \mathrm{~g}$ ${ }^{1}$ meat. These results confirm the data from sensory estimated beef odour and flavour and were evidence for a proteolysis.

Table 2 Effect of the three-component antioxidant blend superficial treatment on the $\mathrm{pH}$ and free amino nitrogen content of beef $m$. semimembranosus packaged under vacuum and rich of oxygen modified atmosphere during storage at $0 \pm$ $0.5^{\circ} \mathrm{C}$

\begin{tabular}{|c|c|c|c|}
\hline Samples & $\begin{array}{c}\text { Storage } \\
\text { time, } \\
\text { d }\end{array}$ & $\mathbf{p H}$ & $\begin{array}{l}\text { Free amino nitrogen } \\
\mathrm{mg} \cdot \mathrm{kg}^{-1} \text { meat }\end{array}$ \\
\hline \multirow{5}{*}{ Control samples C } & 1d & $5.49^{a} \pm 0.03$ & $0.22^{\mathrm{a}} \pm 0.09$ \\
\hline & $7 d$ & $5.83^{\mathrm{b}} \pm 0.02$ & $4.15^{b} \pm 0.52$ \\
\hline & 14d & $5.83^{b} \pm 0.04$ & $5.07^{\mathrm{c}} \pm 0.48$ \\
\hline & 21d & $6.09^{c} \pm 0.05$ & $8.75^{\mathrm{d}} \pm 0.47$ \\
\hline & 28d & $6.49^{\mathrm{d}} \pm 0.06$ & $10.04^{\mathrm{e}} \pm 0.39$ \\
\hline \multirow{5}{*}{ Samples VP } & 1d & $5.49^{a} \pm 0.03$ & $0.22^{\mathrm{a}} \pm 0.09$ \\
\hline & 7d & $5.54^{\mathrm{a}} \pm 0.04$ & $3.86^{\mathrm{b}} \pm 0.50$ \\
\hline & 14d & $5.56^{\mathrm{a}} \pm 0.05$ & $4.69^{c} \pm 0.63$ \\
\hline & 21d & $5.61^{\mathrm{b}} \pm 0.04$ & $5.29^{d} \pm 0.53$ \\
\hline & 28d & $5.62^{b} \pm 0.02$ & $6.04^{\mathrm{e}} \pm 0.45$ \\
\hline \multirow{5}{*}{ Samples AVP } & 1d & $5.49^{a} \pm 0.03$ & $0.22^{\mathrm{a}} \pm 0.09$ \\
\hline & 7d & $5.63^{b} \pm 0.03$ & $3.94^{\mathrm{b}} \pm 0.51$ \\
\hline & 14d & $5.64^{b} \pm 0.04$ & $4.87^{\mathrm{c}} \pm 0.50$ \\
\hline & 21d & $5.66^{\mathrm{b}} \pm 0.04$ & $5.83^{\mathrm{d}} \pm 0.43$ \\
\hline & 28d & $5.75^{\mathrm{c}} \pm 0.04$ & $6.42^{\mathrm{e}} \pm 0.48$ \\
\hline \multirow{5}{*}{ Samples MAP } & 1d & $5.49^{a} \pm 0.03$ & $0.22^{\mathrm{a}} \pm 0.09$ \\
\hline & $7 d$ & $5.47^{\mathrm{a}} \pm 0.04$ & $3.68^{b} \pm 0.36$ \\
\hline & 14d & $5.78^{b} \pm 0.03$ & $4.63^{c} \pm 0.45$ \\
\hline & 21d & $5.81^{\mathrm{b}, \mathrm{c}} \pm 0.04$ & $5.32^{d} \pm 0.46$ \\
\hline & 28d & $5.87^{\mathrm{c}} \pm 0.04$ & $6.01^{\mathrm{e}} \pm 0.48$ \\
\hline \multirow{5}{*}{ Samples AMAP } & 1d & $5.49^{\mathrm{a}} \pm 0.03$ & $0.22^{\mathrm{a}} \pm 0.09$ \\
\hline & $7 d$ & $5.64^{\mathrm{b}} \pm 0.03$ & $3.89^{b} \pm 0.36$ \\
\hline & 14d & $5.75^{\mathrm{c}} \pm 0.05$ & $4.75^{\mathrm{c}} \pm 0.41$ \\
\hline & 21d & $5.78^{\mathrm{c}} \pm 0.04$ & $5.52^{\mathrm{d}} \pm 0.39$ \\
\hline & 28d & $5.84^{\mathrm{d}} \pm 0.04$ & $6.31^{\mathrm{e}} \pm 0.33$ \\
\hline
\end{tabular}

Means \pm standard divinations

$\mathrm{a}, \mathrm{b}, \mathrm{c}, \mathrm{d}, \mathrm{e}-$ indexes show data with statistical different value in columns $(\mathrm{p}<0.05)$ 


\section{Microbiological examinations}

The standard examined microbiological indices for freshness and hygiene of samples were in the norms during whole 28 th day period of storage at $0 \pm 0.5^{\circ} \mathrm{C}$ (Table 3). These results was evidence that all examined samples meet the requirements of Regulation (EC) № 1441/2007. The only exception was found in control samples $\mathrm{C}$ on the $28^{\text {th }}$ day of storage. In these samples a triple increase of the E.coli growth was determined

The similar results were observed for the Enterobacteriaceae spp. In samples VP AVP, MAP and AMAP the absence or very limited growth of Enterobacteriaceae spp., determined between $14^{\text {th }}$ and $28^{\text {th }}$ day of storage at $0 \pm$ $0.5^{\circ} \mathrm{C}$ were found. In contrast, in control samples $\mathrm{C}$ was established systematic irregular increase in the Enterobacteriaceae spp, more pronounced after $21^{\text {st }}$ day of storage when viewed 128.6 times more colonies, and further - on the $28^{\text {th }}$ day - 653.6 times. However, the Brochothrix thermosphacta colonies increased significantly ( $\mathrm{p} \leq 0.05)$, but on the end of storage $\left(28^{\text {th }}\right.$ day) not exceed 50000 1890000 cfu.g in different samples. The most pronounced increase was rapidly detected in control samples C - 9450 times from the initial number. Ten-fold smaller number of Brochothrix thermosphacta colonies was determined in samples AMAP. The slowest increase of the Brochothrix thermosphacta colonies - only 250 times was found in samples AVP.

Table 3 Effect of the three-component antioxidant blend superficial treatment on the microbiological status of beef $m$. semimembranosus packaged under vacuum and rich of oxygen modified atmosphere during storage at $0 \pm 0.5^{\circ} \mathrm{C}$

\begin{tabular}{|c|c|c|c|c|c|c|c|}
\hline Samples & $\begin{array}{l}\text { Storage time } \\
\text { at } 0 \pm 0.5^{\circ} \mathrm{C}, \mathrm{d}\end{array}$ & $\begin{array}{c}\text { Total mesophilic } \\
\text { aerobic and } \\
\text { facultative } \\
\text { anaerobic } \\
\text { microorganisms, } \\
\text { cfu/g } \\
\text { Norm } 5.10^{5}-5.10^{6} \\
\text { cfu/g }\end{array}$ & $\begin{array}{c}\text { Brochothrix } \\
\text { termosphacta, } \\
\text { cfu/g Norm is } \\
\text { not } \\
\text { listed }\end{array}$ & $\begin{array}{c}\text { Enterobacteriaceae, } \\
\text { cfu/g } \\
\text { Norm is not } \\
\text { listed }\end{array}$ & $\begin{array}{c}\text { Escherichia coli, cfu/g } \\
\text { Norm } 500-5000 \text { cfu.g } \\
1\end{array}$ & $\begin{array}{l}\text { Salmonella spp., } \\
\text { Presence in } 25 \mathrm{~g} \\
\text { Norm: Absence } \\
\text { in } 25 \mathrm{~g} \text { sample }\end{array}$ & $\begin{array}{l}\text { L. monocytegenes, } \\
\text { Presence in } 1 \mathrm{~g} \\
\text { Norm: Absence in } \\
1 \mathrm{~g} \text { sample }\end{array}$ \\
\hline \multirow{5}{*}{$\begin{array}{l}\text { Control } \\
\text { samples C }\end{array}$} & 1d & $534^{\mathrm{a}} \pm 38$ & $200^{a} \pm 24$ & $28^{a} \pm 15$ & $20^{a} \pm 8$ & - & - \\
\hline & $7 d$ & $1938^{b} \pm 28$ & $970^{b} \pm 37$ & $50^{\mathrm{a}, \mathrm{b}} \pm 8$ & $40^{b} \pm 7$ & - & - \\
\hline & 14d & $321000^{c} \pm 592$ & $130000^{c} \pm 146$ & $60^{b} \pm 10$ & $50^{b} \pm 10$ & - & - \\
\hline & 21d & $962400^{d} \pm 2608$ & $784000^{d} \pm 569$ & $3600^{c} \pm 187$ & $3300^{c} \pm 155$ & - & - \\
\hline & 28d & $2314000^{\mathrm{e}} \pm 4183$ & $1890000^{\mathrm{e}} \pm 1258$ & $18300^{\mathrm{d}} \pm 433$ & $15200^{d} \pm 373$ & - & - \\
\hline \multirow{5}{*}{ Samples VP } & 1d & $534^{a} \pm 38$ & $200^{\mathrm{a}} \pm 24$ & $28^{a} \pm 15$ & $20^{\mathrm{a}} \pm 8$ & - & - \\
\hline & $7 d$ & $1606^{b} \pm 36$ & $760^{b} \pm 30$ & - & - & - & - \\
\hline & 14d & $20300^{c} \pm 384$ & $25000^{c} \pm 133$ & - & - & - & - \\
\hline & 21d & $71400^{d} \pm 548$ & $50000^{d} \pm 487$ & - & - & - & - \\
\hline & 28d & $195200^{\mathrm{e}} \pm 837$ & $130000^{\mathrm{e}} \pm 792$ & $26^{\mathrm{a}} \pm 13$ & $19^{a} \pm 8$ & - & - \\
\hline \multirow{5}{*}{$\begin{array}{l}\text { Samples } \\
\text { AVP }\end{array}$} & 1d & $534^{a} \pm 38$ & $200^{a} \pm 24$ & $28^{a} \pm 15$ & $20^{\mathrm{a}} \pm 8$ & - & - \\
\hline & $7 d$ & $960^{\mathrm{b}} \pm 24$ & $850^{\mathrm{b}} \pm 32$ & - & - & - & - \\
\hline & 14d & $12300^{\mathrm{c}} \pm 348$ & $6200^{c} \pm 90$ & - & - & - & - \\
\hline & 21d & $44600^{d} \pm 894$ & $7000^{d} \pm 355$ & - & - & - & - \\
\hline & 28d & $179000^{\mathrm{e}} \pm 1000$ & $50000^{e} \pm 669$ & $14^{\mathrm{a}} \pm 9$ & $10^{\mathrm{a}} \pm 7$ & - & - \\
\hline \multirow{5}{*}{$\begin{array}{l}\text { Samples } \\
\text { MAP }\end{array}$} & 1d & $534^{\mathrm{a}} \pm 38$ & $200^{\mathrm{a}} \pm 24$ & $28^{\mathrm{a}} \pm 15$ & $20^{a} \pm 8$ & - & - \\
\hline & $7 d$ & $1380^{b} \pm 27$ & $1240^{b} \pm 95$ & - & - & - & - \\
\hline & 14d & $4118^{c} \pm 93$ & $3200^{c} \pm 55$ & - & - & - & - \\
\hline & 21d & $321000^{\mathrm{d}} \pm 837$ & $68000^{d} \pm 852$ & - & - & - & - \\
\hline & 28d & $981800^{\mathrm{e}} \pm 2049$ & $121000^{\mathrm{e}} \pm 1653$ & - & - & - & - \\
\hline \multirow{5}{*}{$\begin{array}{l}\text { Samples } \\
\text { AMAP }\end{array}$} & 1d & $534^{a} \pm 38$ & $200^{\mathrm{a}} \pm 24$ & $28^{a} \pm 15$ & $20^{a} \pm 8$ & - & - \\
\hline & $7 d$ & $820^{b} \pm 26$ & $400^{b} \pm 23$ & - & - & - & - \\
\hline & 14d & $980^{c} \pm 286$ & $640^{c} \pm 28$ & - & - & - & - \\
\hline & 21d & $104200^{d} \pm 707$ & $12500^{d} \pm 410$ & - & - & - & - \\
\hline & 28d & $878800^{\mathrm{e}} \pm 3564$ & $189000^{\mathrm{e}} \pm 806$ & $27^{\mathrm{a}} \pm 11$ & $16^{a} \pm 6$ & - & - \\
\hline
\end{tabular}

Means \pm standard divinations

$a, b, c, d$ - indexes show data with statistical different value in columns $(\mathrm{p}<0.05)$ Legend: With the sign "-" is result marked "is not detectable".

\section{DISCUSSION}

Similarly to our results Djenane et al. (2003) found a significant reduction of the sensory evaluated colour scores after addition of rosemary and ascorbic acid mixture. Those authors (Djenane et al., 2003) explain their findings by the rates of metmyoglobin formation and the extended shelf-life from about 10 to 20 days. Our results about sensory evaluated odor were confirmed and by findings of Rojas and Brewer (2007) which were determined the effect of $0.02 \%$ rosemary oleoresin on colour stability of cooked beef patties stored at $4^{\circ} \mathrm{C}$ for 8 days. At the end of storage $\left(28 \mathrm{~d}\right.$ at $\left.0 \pm 0.5^{\circ} \mathrm{C}\right)$ the determined light off-odor in samples VP, AVP and MAP, were associated with lipid oxidation rancidity, and described as a smell of wet cardboard. The MAP of beef gives brightly red colour on the meat surface, but high oxygen content in MAP leads to rancid taste, while meat is still attractive red. The high oxygen atmosphere promotes the myoglobin oxidation and prolongs the time for metmyoglobin formation on meat surface (Kim et al., 2010). However, up to $21^{\text {st }}$ day of storage samples AVP received comparatively higher sensory evaluated flavor scores. The main reason was the use of DHQ as inhibitor of lipid oxidation (Semenova et al., 2008), which in combination with rosemary (Ahn et $\boldsymbol{a l . , 2 0 0 2 )}$ and ascorbic acid effectively preserve the bright red beef colour and reduce the worm over-flavor scores. The results obtained for colour brightness $\left(\mathrm{L}^{*}\right)$ can be explained with properties of antioxidants used in TAB. Rich in phenolic components rosemary extract show strong activity and separating $\mathrm{H}^{+}$ions removed hydrogen peroxide and reactive oxygen radical species (Brewer, 2011). L-ascorbic acid donate hydrogen, chelate metal ions (i.e. $\left.\mathrm{Fe}^{2+}\right)$, scavenge free radicals and quencher the peroxyl $\left(\mathrm{O}_{2}^{-\bullet}\right)$ radicals (Brewer, 2011). On the other hand, DHQ release $\mathrm{H}^{+}$protons and reduce prooxidant activity of metal ions with mobile valence such as iron and copper ions, "free" and heme iron (Silva et al.,_2002).
The results obtained about colour redness (a*) confirm the hypothesis of Lund $\boldsymbol{e t}$ al. (2007) who claim that in high oxygen atmospheres rosemary extract protected the fresh red meat colour. Our results are similar to Akarpat et al. (2008) research about use of hot-water rosemary extracts for prevention of colour changes in beef patties, and confirm Rohlik et al. (2012) findings about positive effect of RE addition on colour in the dried/cooked sausages. A TAB which is a powerful polyphenolic antioxidant and plays role of an inhibitor of free radical formation (Silva et al.,_2002) probably reduced velocity of the oxymyoglobin oxidation in AMAP samples. Similarly to our findings about colour stability Berruga et al. (2005) confirmed optimal levels in VP and MAP lamb $m$ longissimus dorsi. Berruga et al. (2005) confirm that after $7^{\text {th }}$ day of refrigeration storage at $2^{\circ} \mathrm{C}$, the $b^{*}$ value increased and $a^{*}$ value decreased. The results of the Berruga et al. (2005) regarding colour lightness (L*) were opposite of our findings. The analysis of those results showed that the combination between superficial treatment with $0.02 \% \mathrm{TAB}$, and MAP can stabilize $\mathrm{L}^{*}$, and $\mathrm{a}^{*}$ values, and was able to minimize the increase of $b^{*}$ value of fresh beef comparing with vacuum and air packaging.

When commenting the $\mathrm{pH}$ of the control samples $\mathrm{C}$ it should be noted that they were in the process of deep deterioration with a strong sour smell, probably caused by the development of lactic acid bacteria (Blixt and Borch, 2002) Under similar conditions, a higher $\mathrm{pH}$ can accelerate the respiratory activity of the muscle tissue and to form a purple deoxymyoglobin (Rhee et al., 2004). This explains the purple colour of VP samples. On the other hand, most myoglobinreducing activity was recorded at $\mathrm{pH} 7.4$ (Hutchison et al., 2010). The myoglobin reduction decreased with $\mathrm{pH}$ decline to 5.7 (the $\mathrm{pH}$ established at the end of the storage). The lower $\mathrm{pH}$ values in samples VP can be caused by more rapid development of anaerobes (Blixt and Borch, 2002), or comparatively high activity of lactic acid bacteria (Borch et al., 1996) under those conditions. Our results showed that the beef treatment with $0.02 \% \mathrm{TAB}$ had no effect on the $\mathrm{pH}$ 
changes of meat and the main factor for MAP beef spoilage was the growth of lactic acid bacteria. At comparatively low $\mathrm{pH}$ and higher osmotic pressure proteolytic enzymes, such as calcium-neutral proteases (Hool and Corry,2007), calpains (Sazili et al.,_2004), or cathepsins (Polidori et al.,_2001) have been activated, in a result of exempted calcium ions in sarcoplasmic reticulum (Geay et al.,2001). Under those conditions bacteria associated with the spoilage of chilled meat, had negative effects such as sour off-flavour, discoloration, gas production, slime production and decrease in $\mathrm{pH}$, and consist except of Brochothrix thermosphacta, Carnobacterium spp., Lactobacillus spp., Leuconostoc spp. and Weissella spp. (Borch et al.,1996). While the Brochothrix thermosphacta dominates in MAP beef (Baranyi et al.,_1996), the main microflora in VP beef was probably lactic acid bacteria (Blixt and Borch, 2002). More favourable microbiological results in VP beef can be explained by the suppression of Brochothrix thermosphacta, anaerobic, and lactic acid bacteria, Pseudomonas and Enterobacteriaceae spp. to levels that would not cause meat spoilage (Blixt and Borch, 2002). The growth of aerobic microflora decreases in VP meat (Motoyama et al., 2010). Compared to the control samples C, MAP $\left(80 \% \mathrm{O}_{2} / 20 \% \mathrm{CO}_{2}\right)$ with or without $\mathrm{TAB}$ treatment extend the shelf-life of beef with 14 days. Similarly to our findings Djenane et al. (2003) significantly reduced the rates of microbial growth using the mixture of rosemary and ascorbic acid. The rosemary extract influenced only on the growth of lactic acid bacteria (Fernández-López et al.,2005).

\section{CONCLUSIONS}

The results obtained allowed us to conclude that the packaging of beef in modified atmosphere $\left(80 \% \mathrm{O}_{2} / 20 \% \mathrm{CO}_{2}\right)$, combined with preliminary superficial treatment with $0.02 \%$ TAB containing DHQ, RE, and AA may extend the shelflife of beef stored at $0 \pm 0.5^{\circ} \mathrm{C}$ till $32^{\text {nd }}$ day post mortem (to $28^{\text {th }}$ day of storage) This shelf-life is with 7 days $(25 \%)$ longer in comparison with beef packed under rich in oxygen modified atmosphere or under vacuum. The combination of pretreatment of beef with $\mathrm{TAB}$ and rich in oxygen MAP preserve the sensory properties, stabilize the $\mathrm{L}^{*}$ and $\mathrm{a}^{*}$ values, and provide slower increase of the $\mathrm{b}^{*}$ value. The pre-treatment of beef with TAB and packaging in rich oxygen MAP inhibit the microbial growth and prevent meat spoilage.

\section{ACKNOWLEDGEMENTS}

The author expresses his gratitude to the teams of the Unitemp Ltd. Voyvodinovo village, Plovdiv region, Vitalife Ltd., Sofia, and Alimenti Ltd., Tsaratsovo village, Plovdiv district for the co-operation and support rendered.

\section{REFERENCES}

AHN, J., GRÜN, I. U., FERNANDO, L. N. 2002. Antioxidant properties of natural plant extracts containing polyphenolic compounds in cooked ground beef. Journal of Food Science, 67(10), 1364-1369. http://dx.doi.org/10.1111/j.13652133.1936.tb10290.x

AKARPAT, A., TURHAN, S., USTUN, N. S. 2008. Effect of hot-water extract from myrtle, rosemary, nettle and lemon balm leaves on lipid oxidation and colour of beef patties during frozen storage. Journal of Food Processing and Preservation, 32(1), 117-132. $\quad$ http://dx.doi.org/10.1111/j.1745 4549.2007.00169.x

BAKALIVANOVA, T., KALOYANOV, N. 2012. Effect of taxifolin, rosemary and synthetic antioxidants treatment on the poultry meat lipid peroxidation. Comptes Rendue de l' Academie Bulgare des Sciences, 65(2), 161-168. http://www.medsci.cn/sci/show_paper.asp?id=57cf2903821

BALEV, D., STAYKOV, A., IVANOV, G., DRAGOEV, S., FILIZOV, E., VASSILEV, K., GROZDEVA, T. 2010. Effect of natural antioxidant treatment and modified atmosphere packaging on the quality and shelf-life of chilled beef Agriculture and Biology Journal of North America, 1, 451-457. http://www.scihub.org/ABJNA/PDF/2010/4/1-4-451-457.pdf

BECKER, E. M., NTOUMA, G., SKIBSTED L. H. 2007. Synergism and antagonism between quercetin and other chain-breaking antioxidants in lipid systems of increasing structural organization. Food Chemistry, 103, 1288-1296 http://dx.doi.org/10.1016/j.foodchem.2006.10.034

BERRUGA, M. I., VERGARA, H., GALLEGO, L. 2005. Influence of packaging conditions on microbial and lipid oxidation in lamb meat. Small Ruminant Research, 57(2-3), 257-264.

http://dx.doi.org/10.1016/j.smallrumres.2004.08.004

BLIXT, Y., BORCH, E. 2002. Comparison of shelf life of vacuum-packed pork and beef. Meat Science, 60(4), 371-378. doi:10.1016/S0309-1740(01)00145-0

BORCH, E., KANT-MUERMANS, M. L., BLIXT, Y. 1996. Bacterial spoilage of meat and cured meat products. International Journal of Food Microbiology, $33,103-120$.

http://dx.doi.org/10.1016/0168-1605(96)01135-x

BREWER, S. 2011. Preserving the beef quality with natural antioxidants, $R K M$ Research Knowledge Management, White paper. Product Enhancement Research, Centennial, CO: Cattlemen's Beef Board and National Cattlemen's Beef Association, $16 \mathrm{p}$.
http://www.beefresearch.org/CMDocs/BeefResearch/PE_White_\%20Papers/Pres erving Beef with Natural Antioxidants.pdf

COHEN, N., ENNAJI, H., BOUCHRIF, B., HASSAR, M., KARIB, H. 2007. Comparative study of Microbiological Quality of Raw Poultry meat at various seasons and for different slaughtering processes in Casablanca (Morocco). Journal of Applied Poultry Research, 16, 502-508. http://dx.doi.org/10.3382/japr.2006-00061

DJENANE, D., ESCALANTE, A., RONCALES, P. 2003. Extension of the shelf life of beef steaks packaged in a MAP by treatment with rosemary and display under uv-free lighting Meat Science, 64, 417- 426. http://dx.doi.org/10.1016/s0309-1740(02)00210-3

Ercolini, D., Russo, F., Torrieri, E., Masi, P., Villani, F. 2006. Changes in the spoilage-related microbiota of beef during refrigerated storage under different packaging conditions. Applied and Environmental Microbiology, 72(7), 4663 4671.

http://dx.doi.org/10.1128/aem.00468-06

FERNÁNDEZ-LÓPEZ， J., ZHI， N., ALESON-CARBONELL， L., PÉREZ

ALVAREZ, J. A., KURI, V. 2005. Antioxidant and antibacterial activities of natural extracts: Application in beef meatballs. Meat Science, 69(3), 371-380 http://dx.doi.org/10.1016/i.meatsci.2004.08.004

GEAY, Y., BAUCHART, D., HOCQUETTE, J.-F., CULIOLI, J. 2001. Effect of nutritional factors on biochemical, structural and metabolic characteristics of muscles in ruminants, consequences on dietetic value and sensorial qualities of meat. RND Reproduction Nutrition Development, 41, 1 -26 http://dx.doi.org/10.1051/rnd:2001101

HOOL, L. C., CORRY, B. 2007. Redox control of calcium channels: From mechanisms to therapeutic opportunities, Antioxidants and Redox Signalling, 9, 409-435.

http://dx.doi.org/10.1089/ars.2006.1446

HUTCHISON, S., SEYFERT, M., HUNT, M. C., HIGGINS, J. J. 2010. Effect of $\mathrm{pH}$, lactate cations $(\mathrm{K}, \mathrm{Na}, \mathrm{Ca})$, and lactate ion concentration on in vitro metmyoglobin-redusing activity. Journal of Muscle Foods, 21, 79-86. http://dx.doi.org/10.1111/j.1745-4573.2009.00168.x

KIM, Y. H., HUFF-LONERGAN, E., SEBRANEK, J. G., LONERGAN, S. M 2010. High-oxygen modified atmosphere packaging system induces lipid and myoglobin oxidation and protein polymerization. Meat Science, 85, 759-767. http://dx.doi.org/10.1016/j.meatsci.2010.04.001

LAGERSTEDT, Å., LUNDSTRÖM, K., LINDAHL，G. 2011. Influence of vacuum or high-oxygen modified atmosphere packaging on quality of beef $m$ Longissimus dorsi steaks after different ageing times. Meat Science, 87, 101-106. http://dx.doi.org/10.1016/j.meatsci.2010.08.010

LARICK, D. K., TURNER, B. E. 1990. Flavor characteristics of forage and green fed beef as influence by phospholipid and fatty acid composition differences. Journal of Food Science, 55, 312-317. http://dx.doi.org/10.1111/j.1365-2621.1990.tb06751.x

http://search.crossref.org/?q=doi\%3A10.1111\%2Fj.1365-2621.1990.tb06751.x LINDAHL, G., MANCINI, R., MILKOWSKI, A., MOHAN, A., POHLMAN, F., RAINES, CH., SEYFERT, M., SØRHEIM, O., SUMAN, S., WEBER, M. 2012 Guidelines, instrumental meat colour measurement. AMSA Meat colour measurement guidelines (Section VIII) Champaign Il: American Meat Science Association, 45-52.

http://www.meatscience.org/AMSAMeatColorMeasurementGuidelines.aspx

LORENZO, J. M., GARCI'A FONTÁN, M. C., FRANCO, I., CARBALLO, J 2008. Proteolytic and lipolytic modifications during the manufacture of dry-cured lacón, Spanish traditional meat product: Effect of some additives. Food Chemistry, 110, 137-149. http://dx.doi.org/10.1016/j.foodchem.2008.02.002 LUND, M. N., HVIID, M. S., SKIBSTED, L. H. 2007. The combined effect of antioxidants and modified atmosphere packaging on protein and lipid oxidation in beef patties during chill storage. Meat Science, 76(2), 226-233 doi:10.1016/j.meatsci.2006.11.003.

MANCINI, R. A., HUNT, M. C., 2005. Current research in meat colour. Meat Science, 71, 100-121. http://dx.doi.org/10.1016/j.meatsci.2005.03.003.

MEILGAARD, M., CIVILL, G. V., CARR, B. T. 2006. Selection and training of panel members. Sensory Evaluation Techniques. Fourth Edition (Chapter 9), Boca Raton FL: CRC Press Taylor \& Francis Group LLC, 141-172. ISBN 9780849338397

MOTOYAMA, M., KOBAYASHI, M., SASAKI, K., NOMURA, M. MITSUMOTO, M. 2010. Pseudomonas spp. converts metmyoglobin into $\begin{array}{llll}\text { deoxymyoglobin. } & \text { Meat } & \text { Science, } & 84(1),\end{array}$ http://dx.doi.org/10.1016/j.meatsci.2009.08.050

NASTASIJEVIC, I., MITROVIC, R., BUNCIC, S. 2009. The occurrence of Escherichia coli $O 157$ in/on faeces, carcasses and fresh meats from cattle. Meat Science, 82(1), 101-105. http://dx.doi.org/10.1016/j.meatsci.2008.12.007

POLIDORI, P., TRABALZA-MARINUCCI, M., FANTUZ, F., POLIDORI, F 2001. Post mortem proteolysis and tenderization of beef muscle through infusion of calcium chloride. Animal Research, 50, 223-226. http://dx.doi.org/10.1051/animres:2001128

PIKNOVÁ, L., ŠTEFANOVICOVÁ, A., DRAHOVSKÁ, H., SÁSIK, M. KUCHTA, T. 2002. Detection of Salmonella in food, equivalent to ISO 6579, by 
three-days polymerase chain reaction-based method. Food Control, 13, 191-194 http://dx.doi.org/10.1016/s0956-7135(01)00099-8

RHEE, M. S., WHEELER, T. L., SHACKELFORD, S. D., KOOHMARAIE, M. 2004. Variation in palatability and biochemical traits within and among eleven beef muscles. Journal of Animal Science, 82, 534-550.

http://www.journalofanimalscience.org/content/82/2/534.full.pdf + html

ROHLIK, B.-O. PIPEK, P., PANEK, J. 2010.The effect of natural antioxidants on the colour of dried/cooked sausages. Czech Journal of Food Science, 28, 249257. http://81.0.228.28/publicFiles/26111.pdf

ROHLIK, B.-O. PIPEK, P., PANEK, J. 2012. Rosemary extract and its affects on meat products' properties. Fleischvirtschaft International, 27, 70-74. http://english.fleischwirtschaft.de/content/epaper/data/022012/index.html

ROJAS, M. C., BREWER, M. S. 2007. Effect of natural antioxidants on oxidative stability of cooked, refrigerated beef and pork. Journal of Food Science, 72, S282-S288. http://dx.doi.org/10.1111/j.1750-3841.2007.00335.x

RUSSO, F., ERCOLINI, D., MAURIELLO, G., VILLANI, F. 2006. Behaviou of Brochothrix thermosphacta in presence of other meat spoilage microbial $\begin{array}{llll}\text { groups. } & \text { Food } & \text { Microbiology, } & \text { 23, }\end{array}$ http://dx.doi.org/10.1016/j.fm.2006.02.004

SAS. 2002. User's guide, release 8.2 edition, Cary, NC: SAS Institute Inc., 80 p. ISBN http://support.sas.com/documentation/onlinedoc/v82/

SAZILI, A. Q., LEE, G. K., PARR, T., SENSKY, P. L., BARDSLEY, R. G., BUTTERY, P. J. 2004. The effect of altered growth rates on the calpain proteolytic system and meat tenderness in cattle. Meat Science, 66(1), 195-201. http://dx.doi.org/10.1016/s0309-1740(03)00091-3.

SCOTTER, S. L., LANGTON, S., LOMBARD, B., SCHULTEN, S. NAGELKERKE, N., IN'T VELD, P. H., ROLLIER, P., LAHELLEC, C. 2001 Validation of ISO method 11290. Part 1. Detection of Listeria monocytegenes in foods. International Journal of Food Microbiology, 64, 295-306 http://dx.doi.org/10.1016/s0168-1605(00)00462-1

SEMENOVA, A. A., KUZNJECOVA, T. G., NASONOVA, V. V. 2008 Possibilities to application of dihydroquercetin for stabilising quality of sausages produced from mechanically deboned poultry meat. Tehnologija mesa (Serbia), 49, 113-116. http://scindeks.ceon.rs/article.aspx?artid=0494-98460804113S

SILVA, M. M., SANTOS, M. R., CAROCO, G., ROCHA, R., JUSTINO, G., MIRA, L. 2002. Structure - antioxidant activity relationship of flavonoids: A reexamination. Free Radical Research, 36, 1219-1227. http://dx.doi.org/10.1080/198-1071576021000016472

YETELLA, R. R., MIN D. B. 2008. Quenching mechanisms and kinetics of trolox and ascorbic acid on the riboflavin-photosensitized oxidation of tryptophan and tyrosine. Journal of Agriculture and Food Chemistry, 56 (22), 10887-10892. http://dx.doi.org/10.1021/jf8006739

VLADIMIROV Y. A., PROSKURNINA E. V., DEMIN E. M., MATVEEVA N. S., LUBITSKIY, O. B., NOVIKOV, A. A., IZMAILOV, D. Y., OSIPOV, A. N., TIKHONOV, V. P., KAGAN, V. E. 2009. Dihydroquercetin (taxifolin) and other flavonoids as inhibitors of free radical formation at key stages of apoptosis. Biochemistry (Moscow), 74(3), 301-307. http://dx.doi.org/10.1134/s0006297909030092

YOUNG, O. A., WEST, J., HART, A. L., VAN OTTERDIJK, F. F. H. 2004. A method for early determination of meat ultimate $\mathrm{pH}$. Meat Science, 66(2), 493 498. http://dx.doi.org/10.1016/s0309-1740(03)00140-2 